\title{
Translating Romantic Sensibility: Narsinhrao Divetiya's Poetry
}

Rakesh Desai

\begin{abstract}
Narasinhrao Divetiya (1859-1937), the well-known Gujarati poet, critic and linguist, modeled his poetry consciously on the British Romantic lyrics and translated the Romantic sensibility into Gujarati poetry through his anthology, Kusummala (1887). This anthology presents complete or partial translations of poems by Wordsworth, Keats, Shelley, Byron and other British romantic poems. The paper shows how Divetiya uses various strategies of translation such as direct translation, free translation, transcreation and teeka to generate a new literary sensibility in Gujarati. Narasinhrao Divetiya's lifelong association with the act of translation made available a Gujarati version of the British romantic lyric and its cognate sensibility and taste.
\end{abstract}

Nineteenth-century renaissance in Gujarat made English education and English literature available to the native Gujaratis. Further, the fourth part of F.T. Palgrave's Golden Treasury (1861), with the poems of the British romantic poets like Wordsworth, Keats, Shelley and Byron, was frequently prescribed as a textbook in schools and colleges of Gujarat. Narsinhrao Divetiya (1859-1937), a major poet, critic and linguist, modeled his poetry consciously on the British romantic lyrics and proposed to translate their allied sensibility and taste into Gujarati poetry and Gujarati readership through his anthology Kusummala (1887). This anthology, along with his other anthologies, also presents complete or partial translations in various forms of the poems by Wordsworth, Keats, Shelley, Byron and others. The pronounced pitch of romanticism in Gujarati poetry is invariably linked with the act of translation in the

Translation Today Vol. 3 Nos. 1 \& 2, 2006 C CIIL 2006 
Translating Romantic Sensibility:

Narsinhrao Divetiya's Poetry

colonial context, not ignoring at the same time native Sanskrit tradition and Charani folk literature.

Needless to say, the concepts of "romanticism" and "translation" themselves are at stake at the moment, and a historical perspective may contextualize them meaningfully. Dalpatram's poem "Bapani Pinpar" (1845) inaugurated modern Gujarati poetry as it adopted Gujarati, leaving the Vraj language, and chose Nature as the subject matter. It markedly differentiated itself from the didactic, religious medieval Gujarati poetry. Dalpatram was closely associated with Alexander Forbes, a British officer. He celebrated his friendship with him in "Forbes vilas" (1867) and commemorated his death in "Forbes virah" (1865), the first elegy in Gujarati. But Dalpatram still wrote in pragmatic mode, aiming at verbal wit and flashes.

It is Narmadashankar Lalshankar Dave or Narmad (18331886) who brought modernity as well as romanticism to Gujarati poetry by introducing new poetic subjects like love, Nature and freedom. Sundaram, a major twentieth-century Gujarati poet and critic, observes:

The third and the most important feature of Narmad's poetry is the introduction, for the first time, of new subjects or a new way of introducing the old subjects into Gujarati poetry. The number of such poems is more than half of his total poetic corpus. This poetry is of three kinds: the poetry of love, the poetry of Nature, and the poetry of freedom. The last of these kinds of poetry came to be written in Gujarati for the first time by Narmad. Poetry of love and that of Nature had been written since long. Subjectivity was introduced to the poetry of love by Narmad for the first time, and the subjective element kept developing since then. Narmad contributed to the poetry of natural description by freeing it from its restrictive thematic context and from its function as a subsidiary 
subject, meant only to nourish the main rasa; and thus by making it an independent poetic subject matter. ${ }^{1}$

(Sundaram 1946:39-40)

Narmad, a prolific writer, has a number of poems on the subjects of love, Nature and patriotism. The theme of love is treated in the poems under the general titles of "Premniti," "Priyani vani," "Priyani vani," "Priya ane priyani vani." Poems descriptive of Nature are grouped under the general titles of 'Van varnan', 'Pravas varnan', 'Gram ane srushtisaundaryana varnankavyo'. The poems, embodying the theme of freedom are collected under the general titles of 'Svatantrata', 'Shuravirna lakshano', 'Virkavita', and 'Deshabhiman sambandhi'. Romanticism in such poetry by Narmad would mean a shift from the didactic, religious poetry of the medieval period to the poetry allowing subjectivity with new subjects like love, Nature and freedom.

Though Narmad must be credited with his pioneering contribution to the emergence of modern Gujarati poetry with its romantic strain, he leaves its further cultivation to his descendants. Sundaram comments on the way Narmad's poetry treats the theme of love:

There is hardly any attractive element left in Narmad's poetry other than the specific element of subjectivity in these love poems by Narmad. He shows a genuinely felt passion of love, which is more than physical. A desire for true love also appears in him. But he could never go deeper than the physical level in his poetry.

(ibid. 45)

In the same vein Vishnuprasad Trivedi, a distinguished scholar and a critic, points out the scope left for further development of the theme of Nature in Narmad's poetry: 
Translating Romantic Sensibility:

Narsinhrao Divetiya's Poetry

The Nature poetry of Wordsworth and Coleridge describe a certain mood or sentiment of Nature herself. The poems embodying independent sentiments of Nature herself are yet in a formative phase in Narmad. They are bound to conventions, echoing Sanskrit poets, at some places.

(Trivedi 1964)

In historical terms, Gujarati poetry after Narmad, waits for a more refined and subtle approach to the themes of love and Nature in a subjective poetic mode.

Self, which is centrally located in romanticism, interacted with the British Other in the colonial period of the nineteenthcentury renaissance and accordingly attempted to define itself in the matrix of nodal cultural events. "Gujarat Vernacular Society" was set up by Alexander Forbes, with the help of Dalpatram, in 1848. This body started publishing the magazine, Budhhiprakash, since 1850. Buddhivardhak Sabha was set up by Narmad and his friends in 1851 for social reforms and woman's education. "Forbes Gujarati Sabha" was instituted by Mansukhram Tripathi in 1854 in Mumbai in the memory of Alexander Forbes. It aimed at collecting old Gujarati manuscripts and translation of good English books. The same year the British parliament made the law for educating Indian people in English. In 1857 the British contained the rebellion and the East India Company was replaced by the British Queen's rule. The same year universities were set up in Bombay, Calcutta and Madras and textile industry was set up in Gujarat. Arya Samaj was founded by Dayanand Sarasvati in 1875. The first non-Parsi paper, Gujarati, a weekly, was published by Ichharam Suryaram Desai in 1880, in Mumbai. National Congress was instituted in 1885. It was a fertile period of history, with varied cultural stimulie, allowing an interaction with the British other, creating a shift between two contexts as it happens in an act of translation. Narsinhrao Divetiya's Kusummala was published in 1887. 
Narsinhrao Divetiya declares his romantic project in the Preface to the first edition of Kusummala:

This small collection of sangeetkavyas is published with an idealistic purpose of acquainting the well-informed readers of Gujarat of the way the Western poetry, which is a little different from the poetry of this country, is written with a different method, and this is to be done through examples and not through dry critical discussions, and thus to cultivate a taste for that kind of poetry in them.

(Divetiya 1953:10)

He modelled his sangeetkavyas on the British romantic lyrics and thus attempted to foster a taste for British romanticism in Gujarati readership through the example of Kusummala. All his poems and translations use meters. The poems like "Prem sindhu," ("The ocean of love"), "Bahurup anupam prem dhare" ("Incomparable love assumes various forms"), or "Gan sarit" ("The river of singing"), treat the theme of love with tenderness and largely in a sacred context in meditative tone. "Suryoday" ("The sunrise"), "Sandhya" ("Evening") and "Ratri" ("Night") treat Nature as a valid poetic subject. A number of poems address the cloud and the koel, reminding Wordsworth's "To the Cuckoo," "To the Skylark" and Shelley's "To a Skylark."

Further, "Phoolni sathe ramat" ("Playing with a flower") anticipates T.E. Hulme's idea of romanticism as a belief in man being "intrinsically good, spoilt by circumstances," "a reservoir full of possibilities" (Hulme 1972:94-95). "Kavinun sukh" ("The poet's happiness") points out the tragic alienation of a romantic poet and the consequent creation of a romantic image, an idea well discussed in Frank Kermode's Romantic Image. "Karena" reasserts the romantic theme of hope. 
Translating Romantic Sensibility:

Narsinhrao Divetiya's Poetry

Kusummala and other anthologies carry the poet's teeka or commentary at the end of the anthology in the form of a linguistic, genetic or critical analysis of a poem. In view of Divetiya's romantic project to use poems as examples to cultivate romantic taste, teeka on the poems also functions the same way, and becomes polemical. Further, teeka also becomes an extension of a poem itself, and acquires a textual status. In a way, teeka is a retranslation of a poem which is already a translation of a British romantic lyric.

A translation seems to enjoy the same status with an original poem from a pragmatic viewpoint as Kusummala and later anthologies carry translated versions along with the original poems. This substantiates further that all poetic texts are translations in different forms. The first two four-line stanzas of "Asthir ane sthir prem" ("Unsteady and steady love") are a translation of the first six lines of Wordsworth's "The Primrose of the rock" (Divetiya 1953:114-15). Further, "Prabhat" ("Dawn") is a translation of Shelley's "Dawn" (ibid. 134). Further, "Megh" ("The Cloud") is a "bhashantar" of Shelley's "Cloud" and "Chanda" ("The Moon") is a "nakal" ("a copy") of that poem by Shelley (ibid. 135). "Chanda" presents translation as "nakal" as its subjectmatter (chanda or the moon) is different from that of the source text (megh or the cloud), but the target language text shares the form with the source language text. "Avasan," the last poem of the anthology, sustains "bhavarth" or essence of Shelley's "Music, when soft voices die," the last poem of the fourth part of Palgrave's Golden Treasury (ibid. 136). It is a transcreation of Shelley's poem.

Translation of romanticism acquires a different poetic form in Divetiya's next anthology Hradayveena (1896). Its poems are more dramatic, often with dialogues, and show an intense social awareness. In its preface, Divetiya defines his earlier poetry, barring a few descriptive ones at its end, as "atmalakshi (subjective)" and mainly that of Hradayveena as "parlakshi (objective)" (ibid: 8). British romanticism seems to naturalize itself, reflecting native 
contemporary reality. Vishnuprasad Trivedi aptly remarks that Gujarati romanticism is hardly "revolutionary" (1961: 43). Hradayveena expresses, at least, an acute awareness of the contemporary problems. "Phasi padeli vidhava" ("A widow trapped") presents a widow deceived into a marriage, resulting into her suicide. "Phulmani dasino shap" ("The curse of Phulmani dasi") is based on a real court case of Harimohan Maithi, an elderly husband, who forcibly had consummation with the eleven-year old wife, which was against even the prevalent social custom at that time. The poem, critical of patriarchy, ends with Phulmani's death. Besides, poems like "Matsyagandha ane Shantanu" ("Matsyagandha and Shantanu") and "Uttara ane Abhimanyu" ("Uttara and Abhimanyu") embody myths from the Mahabharata. Along with such "objective" poems, "Jagatna vishno utar" ("Curing the worldly poisoning") expresses the romantic idea of Nature as a beneficent agency. Moreover, teeka at the end mentions that "Phasi padeli vidhava" ("A childwidow trapped") was inspired ("prerit") by Tennyson's "Forlorn" and became an independent poem. Here translation means as an inspired version of the original-a transcreation. The anthology does not mention any other source language text.

Noopurjhankar (Divetiya 1914) carries many translations, and with an extensive teeka, occupying almost half of the volume. "Chhoopa ansun" ("Hidden tears") presents the romantic notion of the value of tears or passions. Further, it seems to combine the subjective and the objective nature of earlier anthologies, respectively, of Kusummala (ibid. 1887) and Hradayveena (ibid. 1934) in terms of, respectively, the recognition of personal sorrow and that of sorrow of the other. It contains translations of certain parts of Edwin Arnold's Light of Asia like "Kisa Gotami," "Mahabhinishkraman" and "Viyogini Yashodhara." Further, the last four-line stanza of "Viraginini Veena" is an unconscious translation of eight lines of Book VI of Light of Asia (ibid. 1914:172). Here translation is rememoration of sanskara. "Mrutyune prarthana" ("A 
Translating Romantic Sensibility:

Narsinhrao Divetiya's Poetry

prayer to death") is a translation of Sarojini Naidu's "Tarry a while, O Death, I cannot die" (ibid: 178-79). "Maranno bhaya" ("Fear of death") translates Keats's sonnet "When I have fear that I may cease to be," which is entitled as "Terror of Death" in Palgrave's Golden Treasury (ibid: 179-80). Curiously, "Mrutyunun maran" ("The death of death") is inspired by a different literary form, the novel Life Everlasting by Marie Corelli (ibid: 181). "Ghuvad" ("The owl") is a transcreation of Edgar Allan Poe's "The Raven" (ibid: 199). Divetiya's teeka on "Joona dhwani" ("The old voices") introduces certain terms about translation. The poem carries vague impressions of a song read years back- "Songs my mother taught me" (ibid: 218). Divetiya uses the term "chhaya" for this kind of translation, which mediates the process of translation between its forms of "bhashantar" and "anukaran." Further, "Sandhyani devine" ("To the goddess of beauty") is an inspired version of Shelley's "Hymn to Asia" (ibid: 223-24). It is notable that "Shunyahraday mughdha" and "Gopinun sammelan" are the translations of Ravindranath Tagore's Bengali songs in the play Ashrumati natak by Jyotindranath.

Smrutisanhita: Ek Karun Prashasti (ibid. 1940) commemorates the death of Narsinhrao Divetiya's son Nalinkant, and carries teeka written by Anandshankar Dhruv, which refers to Tennyson's "In Memoriam," and also to Wordsworth, Browning and others. It contains the celebrated elegy of Gujarati literature "Mangal mandir kholo."

Buddhacharit is a translation of Edwin Arnold's The Light of Asia or The Great Renunciation (Mahabhinishkraman). "Mahabhinishkraman," "Kisa Gotami" and "Viyogini Yashodhara" were published earlier in Noopurjhankar. According to the teeka by Divetiya at the end, the following parts of The Light of Asia are translated: "Prem Prasoon", "Sujatani Katha", "Budhhanun Prabodhan", "Viyogini Yashodhara", "Mahabhinishkraman" omits certain lines from the source language text. It is notable that Divetiya includes Kavi Botadkar's poem "Budhhanun Gruhagaman" also as it 
is about the same theme. For Divetiya, the common theme of Buddhism may well equalize the status of a poem and that of a translation.

Narsinhrao Divetiya'a lifelong association with translation also defined his talent. Mansukhlal Jhaveri, a noted Gujarati critic, comments:

Even the best of Narsinhrao's poetry could not have attained Nhanalal's sobriety, Kant's elegance or Balvantrai's freshness. Narasinhrao's individual talent is limited to that extent. His vision is narrow to that extent. It seems that imitation (anukriti), and not original creation, suits his talent more. I have found only one poem, which would overwhelm and which we would like to murmur day in and day out: "Premal jyoti taro dakhavi, muj jivanpanth ujalya." And it is not an independent poem. Though it is true that that poem is not independent, it is certainly almost independent. "Lead kindly light" was translated by Narsinhrao also, and also by Kant. Kant's translation might have been more "loyal" to the original text, but Kant's translation does not have tenderness, elegance and heartfelt yearning which Narsinhrao's translation has. Only Narsinhrao could manage the sustained rhythm of that poem, penetrating through heart. And that itself is his specific achievement. "Ghuvad" is another such example. It is inspired by Edgar Allan Poe's "Raven." But it is only inspired. All artistic composition, other than the inspiration, is Narsinhrao's only. And Narsinhrao could shine out in that also. Many more examples like "Mne prerata tarakavrunda! A hun avyo re" or "Chanda" can be cited. It can be discerned from all these examples that originality does not suit Narsinhrao's talent.

(Jhaveri 1959:296-297)

It is notable that Narasinhrao Divetiya's creatve writing misses Kant's elegance ("madhurya"), but his translation of "Lead 
Translating Romantic Sensibility:

Narsinhrao Divetiya's Poetry

kindly light" has elegance ("madhurata") which Kant's translation of the same lacks. Further, Mansukhlal Jhaveri, referring to Kusummala, notes that inspiration from life may be better than derivative inspiration in the context of translation in aesthetic terms, but in historical terms such translated versions have their own significance-modern Gujarati poetry was born with Narmad, but it "grew up and blossomed "only with Narsinhrao (ibid: 297). The romantic strain in Gujarati poetry, carried forward later by Balashankar Kanthariya, Nhanalal, Kalapi or Ravaji Patel was fostered in the context of assimilating the other and self-definition, in the context of translation.

Narsinhrao Divetiya'a lifelong association with the act of translation made available a Gujarati version of the British romantic lyric, its cognate sensibility and taste. It is also reflected on the process of translation and realized its mercurial status. Sujit Mukherjee rightly observes:

Quite significantly, we don't have a word in any Indian language that would be the equivalent of the term 'translation.' We borrowed anuvad from Sanskrit (where it means 'speaking after') and tarjuma from Arabic (where it is nearer to 'explicate' or 'paraphrase'). More recent borrowings are rupantar (in Bangla) or vivartanam (in Malayalam) or bhashantar (in Hindi). That we don't have a widely accepted Indian word for 'translation' suggests that the concept itself was not familiar to us. Instead, when we admired a literary text in one language, we used it as a take-off point and composed a similar text in another language. P. Lal's use of the term 'transcreation' may well be most appropriate for such a situation-more so, now that the Advanced Learners Dictionary has sanctified it.

(Mukherjee 2004:45, his italics) 
In this context, Narsinhrao Divetiaya's translation is largely a transcreation of the British romantic texts while it translates its sensibility and taste into Gujarati poetry. As Divetiya informs in his teeka on "Ghuvad," his translation of Edgar Allan Poe's "Raven" is independent of the original except for the despairing refrain "Never more," which is in the context of the dead Lenore in the original poem, and which refers to puzzles of human life in general in the translated version "Ghuvad." Further, his translation of Cardinal Newman's "Lead kindly light" at the request of Mahatma Gandhi could be a celebrated example of transcreation. But the very process of transcreation, in terms of the degree of creation, transcending the original, may complicate the issue further. Moreover, Narsinhrao Divetiya's extensive teekas to the poems are often a retranslation of a translation of a British romantic lyric. Further, these teekas refer to the act of translation as either a bhashantar, or a prerit or inspired version or rememoration of sanskara, chhaya, nakal or anukaran, suggesting, at least, the plural mode of translation. They also suggest the problematic status of a source language text which ranges from being a sanskara to a literal text. The teekas create a conceptual space wherein the issue of translation may be discussed in the context of empirical practice, keeping up its richness and complexity.

\section{NOTES}

1. All the quotations from Gujarati texts, cited in this paper, are my translations. 
Translating Romantic Sensibility:

Narsinhrao Divetiya's Poetry

\section{REFERENCES}

Divetiya, Narsinhrao Bholanath 1953 "Preface to the first edition" Kusummala Ahmedabad: Gurjar Grantharatna Karyalaya.

1934 "Preface to the $1^{\text {st }}$ edition." Hradayaveena Mumbai: C. Jamanadas Co.

1914 Noopurjhankar Ahmedabad: Union Printing Press.

1940 Smaransanhita: ek karun prashasti Ahmedabad: C. Jamanadas Co.

Hulme, T. E. 1972 "Romanticism and classicism" in David Lodge (ed) 20th Century Literary Criticism: A Reader London: Longman.

Jhveri, Manasukhalal 1959 "Narasinhrao" Thoda Vivechanlekho Ahmadabad: Gurjar granthratna karyalaya.

Mukherjee, Sujit 2004 "Transcreating Translation" in Meenakshi Mukherjee (ed) Translation as Recovery Delhi: Pencraft International.

Sundaram 1946 Arvachin Kavita: 1845 pachhni kavitani rooprekha Ahmedabad: Gujarat Vernacular Society.

Trivedi, Vishnuprasad 1961 "Arvachin sahitya ane vivechanman kautukrag" in Kunjavihari Maheta et al. (ed) Upayan: Shri Vishnuprasad R. Trivedi shashtipoorti abhinandan granth Surat: Shri Vishnuprasad Trivedi shashtipoorti sanman samiti.

1964 "Narmad" Vivechana Ahmedabad: Gurjar Granthratna Karyalaya. 
